навчання складають такі правила: швидкість навчання зростає, якщо навчальний матеріал представлений у вигляді дискретних частин; студент повинен реагувати, матеріал запам'ятовується краще, якщо студент бере активну участь у навчальному процесі. Також додамо до цих правил, що соціально-інформативна насиченість навчального процесу й самостійної навчальної діяльності дозволяє забезпечити емоційне залучення студента до процесу засвоєння інформації, що створюється за рахунок оперативного активного реагування та позитивного підкріплення, а позитивні емоції, будучи «каталізатором» інтелектуальної активності особистості, здатні підвищити ефективність засвоєння навчального матеріалу як безпосередньо, так і на відстані. Дидактична умова соціально-інформативної насиченості дозволяє поєднати сучасний технічний інструментарій із суспільними та особистісними реаліями.

Дистанційна самостійна навчальна діяльність, що базується на використанні сучасних мультимедіа - відносно нова організаційна форма. Вона грунтується на інтеграції кращих традиційних методів навчання й нових інформаційно-комунікаційних технологій, принципах самостійного навчання. У межах цього різновиду самостійної навчальної діяльності апробуються нові методи та прийоми, процес самостійної навчальної діяльності може відбуватися будь-де й будь-коли, єдина умова - технічне забезпечення доступу до мережі internet. Серед таких новітніх методів дослідники виокремлюють:

- кейс-методи - сукупність методів самостійної дистанційної роботи, які засновуються на використанні наборів (кейсів) текстових, аудіовізуальних і мультимедійних навчальнометодичних матеріалів для самостійного вивчення студентами, під час організації та здійснення консультування;

- тьюторські методи - надання тематичної цілеспрямованої допомоги, патронаж самостійної навчальної діяльності студентів за допомогою сучасних комп'ютерних технологій;

- мережеві технології та похідні від них методи - базуються на оперативному використанні матеріалів освітніх сайтів, інструктивних і навчально-методичних матеріалів тощо.

Отже, самостійна навчальна діяльність сприяє формуванню у студентів інтелектуальних якостей, необхідних майбутньому спеціалістові. Інформативні ж насиченість в свою чергу сприяє розширенню соціальних можливостей тих, хто навчається, їх медіа грамотності, дозволяє забезпечити емоційне залучення студента до процесу засвоєння інформації, що створюється за рахунок оперативного активного реагування та позитивного підкріплення. Впровадження таких новітніх методів як мережеві технологій, тьоторські методи, кейс-методи, дистанційне навчання забезпечують здійснення самостійної навчальної діяльності студентів перекладацьких спеціальностей в інтерактивному режимі і тим самим мотивує цей вид діяльності.

\title{
Література
}

1. Гончаренко С. У. Український педагогічний словник / Семен Устинович Гончаренко. - К. : Либідь, 1997. - 374 с. 2. Ляховицкий М. В. Теория и практика применения технических средств в обучении иностранным языкам / М.В.Ляховицкий. - К. : Вища школа, $1989 .-255$ с. 3. Сіцінський А. До проблеми структурування професійних знань в інформаційному суспільстві / А. Сіцінський // Педагогіка і психологія професійної освіти. - 2003. - № 2. - С. 40-47. 4. Шпинер Х. Организация знания в информационном обществе / Х. Шпинер // Техника, общество и окружающая середа : материалы международной научной конференции. - М. : МГУ, 1998. - С. 52-54. 5. Усов Ю. Н. Методика использования киноискусства в идейно-эстетическом воспитании / Ю. Н. Усов. - Таллинн, 1980. - 112 с.

\section{ПРОФЕСІЙНА МОТИВАЦІЯ ТА ЇЇ РОЛЬ У ФОРМУВАННІ МОТИВАЦІЇ ДО ВИВЧЕННЯ ІНОЗЕМНИХ МОВ У СТУДЕНТІВ НЕМОВНИХ ВНЗ}

Побережна Н. О. Професійна мотивація та іiі роль у формуванні мотивації до вивчення іноземних мов у студентів немовних ВНЗ.

У статті аналізуються шляхи формування оптимальної мотивації учіння студентів немовних ВНЗ до оволодіння іноземною мовою у процесі навчання. Виявлено умови, що впливають на формування позитивної мотивації слухачів до оволодіння іншомовними здібностями.

Ключові слова: мотивація, мотивація учіння, професійна мотивація, іншомовні здібності. 
Побережная Н. О. Профессиональная мотивация и ее роль в формировании мотивации к изучению иностранных языков у студентов неязыковых вузов.

В статье анализируются пути формирования оптимальной мотивации к изучению иностранных языков студентов неязыковых вузов. Определены условия оказывающие влияние на формирование позитивной мотивации студентов к овладению иноязычными способностями.

Ключевые слова: мотивация, мотивация учения, профессиональная мотивация, иноязычные способности.

Poberezhna N. O. Professional motivation and its role in forming motivation of students for learning foreign languages.

The ways for forming learning motivation of students while learning foreign languages are being analyzed. The conditions influencing the formation of students' positive motivation to master the foreign-language skills have been revealed.

Key words: motivation, motivation of learning, professional motivation, abilities for learning a foreign language.

Із розвитком економічних, політичних і культурних взаємозв'язків України з іншими країнами Європи зростає необхідність у вивченні іноземних мов студентами та слухачами немовних ВНЗ. Наразі суспільство почало усвідомлювати принципово нову роль мовної освіти в сучасному інформаційному світі.

Нині в Україні чимало зроблено для реформування політики в галузі вивчення іноземних мов. Іншомовна освіта реформується з урахуванням досягнень європейських країн у цій галузі та відповідно до базових документів Ради Свропи як «Загальноєвропейські рекомендації 3 мовної освіти: вивчення, викладання, оцінювання», «Європейський мовний портфель», «Приведення екзаменів з мови у відповідність до загальноєвропейських рекомендацій з мовної освіти» та «Вимоги до Євроіспитів». Ідеї мовної політики Ради Європи знаходять все більше визнання в нашій державі. Іншомовна компетентність $\epsilon$ важливою рисою фахівця в галузі економіки, права й державного управління. Реальністю сьогодення $\epsilon$ і те, що прийом фахівців на роботу, зазвичай, здійснюється на базі конкурсного відбору, однією з вимог якого є володіння іноземною мовою, що свідчить про зростаючу соціальну значущість іноземної мови в сучасних соціально-економічних умовах.

Проблемами розвитку іншомовної компетенції фахівців займались такі науковці як I. Агабекян, П. Козик, О. Кричев, Р. Сирнєва, Л. Юрцева, І. Шишкіна, В. Шпак та інші. Проблеми мотивації навчальної діяльності достатньо широко висвітлювались у вітчизняних і зарубіжних дослідженнях. Визначальною позицією $є$ розуміння мотивації як системи спонукань (В. Асєєв, Л. Божович, А. Маркова, Е. Шорохова), тобто як детермінація поведінки в цілому (С. Рубінштейн). Навчальна мотивація розуміється як рушійна сила процесу розвитку особистості, ії пізнавальних потреб (Л. Божович, В. Ільїн, В. Сонін).

Незважаючи на досить великий спектр різнопланових досліджень, пов'язаних із визначенням ролі мотивації для навчальної діяльності, зокрема напрацюванням стосовно формування оптимальної мотивації до оволодіння іноземними мовами студентами немовних ВНЗ, уважного ставлення дослідників вимагає питання комплексного вивчення у структурі мотивації таких складників, як: професійна мотивація, мотивація до оволодіння іноземною мовою та іншомовними здібностями.

Метою статті $є$ визначення шляхів формування оптимальної мотивації учіння у студентів немовних ВНЗ до оволодіння іноземною мовою в процесі навчання.

Загальновідомо, що висока мотивація навчання є ознакою ефективної діяльності. Особливо це стосується немовного ВН3, у якому іноземна мова не є профілюючим предметом, але де саме мотивація учіння, шляхом цілеспрямованого їі формування, може бути перетвореною на реальну рушійну силу процесу оволодіння іноземною мовою та стати одним 3 основних чинників інтенсифікації навчальної діяльності.

Дані психологічних досліджень дозволяють нам з упевненістю стверджувати, що висока позитивна мотивація може компенсувати нестачу спеціальних здібностей або недостатній рівень знань, умінь і навичок, відіграючи роль компенсаторного чинника, проте у зворотному напрямку компенсаторний механізм не спрацьовує. Інакше кажучи, яким би здібним i 
ерудованим не був студент, без бажання й поштовху до навчання він не досягне значних успіхів у навчанні. Від сили і структури мотивації значною мірою залежить як навчальна активність слухачів, так і їхня успішність. Усвідомлюючи те, яке вирішальне значення має для навчальної діяльності мотивація, дослідники сформулювали приничип мотиваційного забезпечення навчального процесу. Багато хто із спеціалістів уважає, що цілеспрямоване формування в учнів мотивації навчально-трудової діяльності необхідне, але, на думку А. Маркової, керувати формуванням мотивів навчальної діяльності ще важче, ніж формувати дії та операції. [4, с. 198] Тому, перш ніж формувати навчальну мотивацію учнів, педагогу необхідно іiі проаналізувати, з'ясувати для себе характер реальності, з якою він буде мати справу, знайти шляхи ії адекватного опису.

Аналіз літератури із психології, де розглядаються проблеми мотивації, дозволяє нам констатувати, що процеси, які викликають або стримують психологічну мотивацію, все ще залишаються проблемою психологічної науки. Виникає цілком слушне припущення про тісні взаємозв'язки здібностей і мотивів діяльності. Не випадково відомий дослідник мотивації А. Маслоу [5, с. 126] у своєму визначенні мотивації неодноразово наголошує, що «це прагнення людини... виявити себе в тому, до чого вона відчуває себе потенційно здібною».

В. Безпалько також трактує поняття мотивації 3 погляду реалізації природжених здібностей: «під мотивацією необхідно розуміти генетичне прагнення людини до самореалізації, згідно з іiі природженими здібностями до певного типу діяльності та наполегливості під час оволодіння нею на творчому рівні. Це активне й стійке прагнення реалізується в цілком очевидні досягнення тільки тоді, коли виникають необхідні умови для цього. В іншому випадку самореалізація більшою чи меншою мірою стримується немотивованими видами діяльності, досягнення в яких не можуть перевищувати виконавчий рівень» $[1$, с. 132].

Вихід із такого становища $Є$. Ільїн бачить у тому, щоб розглядати мотивацію як динамічний процес формування мотиву (як основу вчинка). [3, с. 264] Мотиви є динамічними системами, в яких здійснюються аналіз і оцінка альтернатив, вибір і прийняття рішень. У кожного студента мотиви навчання особисті, індивідуальні, які залежать від особистісних якостей, уподобань та цілей. Мотиви спрямовують, організовують пізнання та надають йому особистісного значення. Внутрішня мотивація, яка в багатьох особистостей $\epsilon$ нестійкою, виникає поступово й перебуває в тісному взаємозв'язку із ситуаціями (цікаві завдання, розв'язання ситуативних завдань, змагання, підтримка викладача тощо). Мотивація навчання, як процес зміни стану і ставлення особистості до діяльності, грунтується на мотивах, під якими розуміються сукупність чинників спонукання до діяльності.

Отже, у процесі формування оптимальної мотивації учіння, зокрема до оволодіння іноземними мовами студентами немовних ВН3, необхідно враховувати природжені здібності студентів та слухачів і створювати умови для їх реалізації. Саме тоді відбувається підсвідоме й інтуїтивне зіставлення в мозку студента його природжених здібностей і вимог педагога щодо застосування інформаційних технологій. Якщо у процесі дії оціночного механізму у студента були виявлені такі необхідні здібності, як прагнення цієї діяльності, виникає те, що А. Маслоу називає «потребою в самоактуалізації», і навчальна мотивація починає працювати на повну силу: студент із задоволенням виконує завдання і прагне виявити себе якомога краще й точно в тому, до чого в нього є природні здібності.

Отже, мотивація, на нашу думку, - не пасивний механізм, що вимагає поштовху, а активний індивідуальний «мотор», який постійно підштовхує людину в те поле діяльності, де їі здібності можуть виявитися з найбільшою силою і гальмує їх виявлення в інших напрямках.

Методика забезпечення розвитку позитивної мотивації навчання вбачається системою та наслідком послідовної взаємодії викладача та студента, яка поєднує сукупність методів і прийомів розвитку позитивної мотивації до навчання і характер взаємодії викладача та студента, передбачає реалізацію підходів організаційного, навчально-виховного характеру.

Основними чинниками, які впливають на формування позитивної мотивації до оволодіння іншомовними здібностями, на наш погляд, $є$ такі:

- зміст навчального матеріалу;

- організація навчальної діяльності;

- застосування комунікативного підходу до навчання іноземній мові; 
- застосування інформаційно-комунікаційних технологій під час навчання іноземній мові;

- стиль педагогічної діяльності педагога.

Проаналізуємо певні з вищевказаних чинників:

Інтерес студентів до спеціальності диктує необхідність добору певного змісту матеріалу, який має суттєве значення для організації мотивованого, зацікавленого спілкування іноземною мовою. Зміст матеріалу повинен бути не дуже простим і не надто складним у понятійному відношенні з урахуванням професійних знань у відповідній галузі. Природно, лінгвістична сторона матеріалу повинна відповідати рівню знань студентів і етапу навчання.

Як зазначено вище, другим чинником $є$ організація навчальної діяльності. На цьому етапі важливим $є$ створювання системи особистих очікувань результату навчання, тобто планувати результат навчання для кожного слухача у вигляді «ступенів просунення» або «карти особистих цілей», де чітко визначити терміни та очікуванні практичні результати. Для підтримки постійних позитивних очікувань, погоджених 3 ціллю навчання, доцільно періодично повертатись до їх обговорення і корекції. Тоді, за умови чіткого погодження цілей, позитивної мотивації та планованих результатах процес навчання стане більш ефективним.

Наступним чинником або умовою є застосування комунікативного підходу до навчання іноземній мові. Так, на думку багатьох науковців, оптимальною може вважатися тільки така структура мотивів у процесі вивчення іноземних мов, головне місце у якій належить безпосередній комунікативній діяльності мовою, що вивчається [9, с. 98]. Саме комунікативна спрямованість на заняттях 3 іноземних мов може забезпечити підвищення мотивації до вивчення іноземних мов.

Відомо, що змінюючи характер спілкування, можна прискорити процес оволодіння іноземною мовою. Виокремлення компонента спілкування припускає створення на заняттях умов спілкування в реальній дійсності, в природному мовному середовищі, що дозволяє створити внутрішню мотивацію до спілкування в умовах комунікативних ситуацій.

Використання рідної мови слухачів у цих умовах слід скоротити до мінімуму, використовуючи його в ситуаціях крайньої необхідності, інакше це нівелює іноземну мову як засіб спілкування на занятті й упускається прекрасна можливість мотивованого використання іноземних мов. Створенню природного мовного середовища на заняттях може сприяти i організація дискусій, обговорення тих або інших проблем, пов'язаних із професійними інтересами слухачів. Це відкриває широкі можливості для спілкування, обміну думками, інтересами, досвідом в тій або іншій галузі знань, пов'язаних із спеціальністю. Викладач у цих умовах природно повинен бути співкомунікантом, одним із групи. Він може спрямовувати i стимулювати, але не перехоплювати ініціативи і відповідальності студентів як рівноправних партнерів по спілкуванню.

Наступним важливим чинником, який впливає на формування позитивної мотивації до оволодіння іншомовними здібностями, є застосування інформаційно-комунікаційних технологій під час навчання. Проблеми застосування комп'ютерних технологій в успішному навчанні іноземних мов розглядаються в працях Е. Полат, А. Трутнєва [8, с. 14]. Ці дослідники підкреслюють, що комп'ютерні технології є ефективним виховним, методичним і дидактичним засобом підвищення якості навчального процесу. Зокрема, інформаційні технології під час вивчення іноземної мови сприяють:

- індивідуалізації навчальної діяльності, максимальній іiі самостійності, іiі творчому характеру;

- максимальній комфортності, відповідності темпу навчальної діяльності індивідуальним особливостям учнів, подоланню комунікативного бар'єра;

- формуванню, у тих хто навчається, комунікативних навичок, культури спілкування;

- формуванню навичок дослідницької діяльності;

- створенню справжнього мовного середовища, насамперед, за рахунок телекомунікаційних контактів з носіями мови;

- створенню підвищеної мотивації до оволодіння мовленнєвими навичками та використання їх у реальних міжособистісних навчальних і ділових контактах.

Унаслідок своєї інтегративності особливе місце 3-поміж методів інформаційнокомунікаційного навчання посідає метод проектів. Щодо головних особливостей методу проектів порівняно з традиційними методами навчання можна зазначити такі: якщо під час 
традиційного навчання одним із важливих завдань викладача $€$ організація відтворення активності учнів (при цьому досягнення правильного виконання завдання здійснювалось на основі показу, пояснення та контролю), то під час застосування методу проектів провідним завданням є організація пошукової активності слухачів. 3-поміж інших можливостей, що надають інформаційно-комунікаційні технології навчання під час оволодіння іноземними мовами, $є$ організація спільних проектів на основі співробітництва студентів та слухачів різних ВНЗ, міст і країн. Однією з форм організації навчальної діяльності слухачів у мережі Інтернет $є$ навчальний телекомунікаційний проект.

Під навчальним телекомунікаційним проектом (за Є. Полат) ми розуміємо спільну навчально-пізнавальну, дослідницьку, творчу або ігрову діяльність студентів-партнерів, що організована на основі комп'ютерної комунікації і має загальну проблему, мету, погоджені методи, способи діяльності, спрямовані на досягнення спільного результату.

Вище згадані умови, за яких відбувається процес підготовки слухачів до оволодіння іноземними мовами із застосуванням інформаційних технологій, засвідчують дієве оволодіння мовленнєвою діяльністю, зокрема, такою як мислення, сприймання інформації та ії узагальнення. Інформаційно-комунікаційні технології сприяють стимулюванню іншомовного мовлення, підсилюючи мотивацію, розширюючи обмін інформаціями між слухачами.

Отже, останньою умовою на етапі формування позитивної мотивації слухачів до оволодіння іншомовними здібностями посідає стиль педагогічної діяльності викладача іноземної мови. Крім компетентності у своїй предметній галузі, для сучасного викладача вищого навчального закладу все більшого значення набувають такі його особистісні параметри, як інтелектуальна мобільність, комунікабельність, позитивне сприйняття нового, готовність до професійного й особистого зростання. Традиційна інформаційна діяльність набуває нового якісного розвитку, наповнюється новим змістом. Педагог як суб'єкт міжкультурної взаємодії займає ключову позицію, від якої залежить реалізація загальноєвропейської освітньої політики.

Отже, можемо говорити про те, що визначальним у формуванні мотивації до вивчення іноземних мов є компонент спілкування, який охоплює комунікативні особливості слухачів, комунікативні якості педагога і взаємодію між ними. Навчання, орієнтоване на активізацію природного спілкування, знижує залежність мотивації учіння у процесі вивчення іноземних мов від рівня розвитку іншомовних здібностей.

\section{Література}

1. Беспалько В. П. Образование и обучение с участием компьютеров (педагогика третьего тысячелетия) / Владимир Павлович Беспалько. - М. : Изд-во Московского психолого-социального инст-та ; Воронеж : Изд-во НПО «МОДЕК», 2002. - 352 с. 2. Загальноєвропейські Рекомендації 3 мовної освіти: вивчення, викладання, оцінювання / Науковий редактор українського видання доктор пед. наук, проф. С.Ю. Ніколаєва. - К. : Ленвіт, 2003. - 273 с. 3. Ильин Е. П. Психология / Евгений Павлович Ильин. - СПб: Питер, 2004. - 560 с. 4. Маркова А. К. Психология профессионализма / Аэлита Капитоновна Маркова. - М. : Международный гуманитарный фонд «Знание», 1996. - 308 с. 5. Maslow A. Motivation and personality / A. Maslow. - 1970. - 204 p. 6. Новые педагогические и информационные технологии в системе образования : учебн. пособие [для студ. педвузов и системы повышения квалификации пед. кадров] / под ред. Е. С. Полат. - М. : Академия, 2000. - 272 с. 7. Пометун О. І. Розвиток компетентністного підходу: стратегічні орієнтири сучасної школи / О.І. Пометун // Реалізація європейського досвіду компетентнісного підходу у вищій школі України: [матеріали методологічного семінару]. - К.: Педагогічна думка, 2009. - 332 - 345. 8. Трутнев А. Ю. Педагогические условия применения компьютерной технологии в процессе обучения студентов университета иностранному языку : автореф. дис. на соискание учен. степени канд. пед. наук /А. Ю. Трутнев ; МаГУ. - Магнитогорск, 2001. - 24 с. 9. William Littlewood. Communicative Language Teaching. An introduction. - Cambridge University Press, 1992. - 124 p. 